\title{
USING FEED ADDITIVES FOR BETTER UTILIZATION OF PHOSPHORUS AND NITROGEN IN BROILERS \\ FEEDS
}

\author{
Ahmed, M. Abdel Aziz ${ }^{(1)}$; Nematallah, G. M. Ali ${ }^{(2)}$; \\ Marwan, A. M. Abdel Aziz ${ }^{(2)}$ and Gihan, M. El-Moghazy ${ }^{(1)}$ \\ 1) Regional Center for Food \& Feed (RCFF), Agriculture Research Center \\ 2) Poultry Production Department, Faculty of Agriculture, Ain Shams \\ University
}

\begin{abstract}
One hundred fifty Arbor Acers broiler chicks were distributed into five groups to study effects of using sodium formate, formic acid, Lactobacillus acidophilus and beta mannanase enzyme, in broiler feeds, on production performance, carcass traits, blood parameters, tibia properties and economic efficiency. Each group of birds, was divided into three replicates of ten chicks. The control group was fed basal (starter, grower and finisher) with no additives (T1), while other groups were offered basal diets supplemented with $2 \mathrm{~g}$ sodium formate/ $\mathrm{kg}$ (T2); $2 \mathrm{ml}$ formic acid / $\mathrm{kg}$ (T3); $1 \mathrm{~g}$ Lactobacillus acidophilus/ $\mathrm{kg}$ (T4) and $0.3 \mathrm{~g}$ beta mannanase/ $\mathrm{kg}$ (T5), respectively. The results indicated that all production performance parameters: initial and final body weight, daily body weight gain, daily feed intake and feed conversion ratio, were not significantly affected by treatments throughout experimental period. Also, data of carcass, indicated that treatments had no significant effects compared with control group. Plasma total protein, uric acid, calcium, phosphorus and activity of alkaline phosphatase, were significantly different within groups. Tibia bone parameters: breaking force, density, robusticity index, Seedor index, were not significantly affected by treatments. Economical evaluation showed that, relative economic efficiency, was improved with chicks fed (T2) or (T3) diets, while those fed (T4) or (T5) diets, recorded lower values. It could be concluded that, supplementation of basal diets with sodium formate or formic acid enhanced economic efficiency of broiler chickens, without affecting performance or carcass traits.
\end{abstract}

Key words: feed additives, performance, carcass, economic efficiency. 


\section{INTRODUCTION}

Poultry excreta contain significant quantities of nitrogen, phosphorus, and other expelled elements which were presented in their feeds (FAO, 2006). Besides, conversion of feed nitrogen is fairly inefficient; about 50 - 80 percent of the nitrogen is excreted (Arogo et al., 2001).

Regarding phosphorus, using plant-based feedstuffs, results in excess phosphorus excretion and might cause ecologic pollution (Nahm and Carlson, 1998). Using organic acids in poultry feeds increase mineral utilization due to the complex of acid anion with calcium, phosphorus, magnesium and zinc, resulting in higher utilization of these minerals (Andreopoulou et al., 2014).

Several scientific reports demonstrated that organic acids might stimulate natural immune response of poultry, reducing activity of pathogenic bacteria (Cross, 2002; Dalloul et al., 2003). As well, formic acid and its salts improve productivity, mineral utilization, protein digestibility, acting against pathogens, which improves bird's immune system. (Hebeler et al., 2000; Desai et al., 2007; Abdelhady et al., 2015). Several nutritional studies indicated that using formic acid or formate salts in broiler feeds, improved mineral utilization (Selle et al., 2004) weight gain (Panda et al., 2009), feed efficiency (Helen and Christian, 2010), feed intake (Abdelaziz, 2015). The function of probiotics as natural feed supplements is based upon inhibiting harmful bacteria and lowering intestinal $\mathrm{pH}$ via production of volatile fatty acids (Makled, 1991; Seleem et al., 2011).

However, probiotics can only be effective, as their growth requirements are present in bird's intestine. Nematallah et al. (2015) reported that, using probiotics at $0.5 \mathrm{~g} / \mathrm{kg}$ feed, appeared adequate to achieve satisfactory results. 
Feed-added enzymes improve nutrient and energy digestibility of poultry feeds (Yang et al., 2010; Hahn-Didde and Purdum, 2014).

Generally, feed viscosity is reduced by plant cell walls breakdown, which includes proteins and antinutritional factors (Cowieson, 2010; Perazzo Costa et al., 2015). Commonly, using nutritional matrix of enzyme products is suggested for feed formulation, allowing reduction of feed energy, phosphorus, protein, and amino acid contents (Campasino et al., 2015), which present benefits of reducing environmental pollution and reduced feed costs (Dersjant-Li et al., 2015).

The present study was carried out to investigate effects of using sodium formate, formic acid, Lactobacillus acidophilus and Beta Mannanase on performance, carcass, blood plasma, tibia bone and economic efficiency of broilers.

\section{MATERIALS AND METHODS}

This study was carried out at poultry production department experimental farm, faculty of agriculture, Ain Shams University, Egypt, in order to investigate the effect of using sodium formate, formic acid, Lactobacillus acidophilus and beta mannanase enzyme, on growth performance, carcass characteristics, blood parameters, tibia traits and economic efficiency of broilers.

Experimental diets and birds: At the present trial, 150 sex-mixed one-dayold age Arbor Acers broiler chicks, distributed over 5 groups up to 35 days of age. Birds were allocated in wire batteries with feed and water provided adlibitum, during whole experimental period. Each treatment contained 3 
replicates of 10 broiler chicks. Daily lighting program was about 22 hours light +2 hours dark. The composition and calculated analyses of basal diets (starter, grower and finisher) are presented in Table (1). The diets were formulated based on corn-soybean meal as prescribed by NRC requirements (1994). Treatments were: T1: (control diet) basal diet without additives; T2: basal diet + sodium formate $2 \mathrm{~g} / \mathrm{kg}$ feed; T3: basal diet + formic acid $2 \mathrm{ml} /$ $\mathrm{kg}$ feed; T4: basal diet + Lactobacillus acidophilus $1 \mathrm{~g} / \mathrm{kg}$ feed and T5: basal diet + beta mannanase enzyme $0.3 \mathrm{~g} / \mathrm{kg}$ feed.

Birds' performance: Live body weight and feed intake for each replicate of all groups during the experimental period were recorded. Body weight gain and feed conversion ratio were calculated during the same period. 
J. Environ. Sci.

Institute of Environmental Studies and Research - Ain Shams University

Table (1): Feed ingredients and chemical analyses of basal diets.

\begin{tabular}{|c|c|c|c|}
\hline \multirow[b]{2}{*}{ Ingredients } & \multicolumn{3}{|c|}{ Basal Diets } \\
\hline & $\begin{array}{c}\text { Starter } \\
(0-14 \text { days })\end{array}$ & $\begin{array}{c}\text { Grower } \\
\text { (15-28 days) }\end{array}$ & $\begin{array}{c}\text { Finisher } \\
\text { (29-35 days) }\end{array}$ \\
\hline Yellow Corn Grains & 51.72 & 57.34 & 62.68 \\
\hline Soy Bean Meal 44\% & 35.00 & 29.79 & 24.70 \\
\hline Corn Gluten Meal 60\% & 5.20 & 4.90 & 4.60 \\
\hline Lime Stone $(\mathrm{CaCO} 3)$ & 1.35 & 1.10 & 1.08 \\
\hline Di-Ca Phosphate & 1.90 & 1.68 & 1.55 \\
\hline Salt $(\mathrm{NaCl})$ & 0.40 & 0.40 & 0.40 \\
\hline Premix* & 0.30 & 0.30 & 0.30 \\
\hline Plant Oil & 3.50 & 4.00 & 4.25 \\
\hline DL-Methionine & 0.31 & 0.24 & 0.21 \\
\hline Lysine $-\mathrm{HCl}$ & 0.32 & 0.25 & 0.23 \\
\hline Total & 100 & 100 & 100 \\
\hline \multicolumn{4}{|c|}{ Calculated Chemical Analysis } \\
\hline Crude Protein \% & 23.01 & 21.01 & 19.04 \\
\hline ME Kcal/ Kg diet & 3046 & 3159 & 3238 \\
\hline Calcium \% & 1.07 & 0.90 & 0.85 \\
\hline Available Phosphorus \% & 0.51 & 0.45 & 0.42 \\
\hline Lysine \% & 1.45 & 1.25 & 1.10 \\
\hline Methionine \& Cysteine \% & 1.08 & 0.95 & 0.87 \\
\hline
\end{tabular}

* Each $3 \mathrm{Kg}$ of premix contains: Vitamins: A: 12000000 IU; D3: 2000000 IU; E: $10000 \mathrm{mg}$; K3: $2000 \mathrm{mg}$; B1:1000 mg; B2: $5000 \mathrm{mg}$; B6:1500 mg; B12: $10 \mathrm{mg}$; Biotin: 50 mg; Choline chloride: 250000 mg; Pantothenic acid: 10000 mg; Nicotinic acid: 30000 mg; Folic acid: 1000 mg; Minerals: Mn: 60000 mg; Zn: 50000 mg; Fe: $30000 \mathrm{mg}$; Cu: $10000 \mathrm{mg}$; $1000 \mathrm{mg}$; Se: $100 \mathrm{mg}$ and Co: $100 \mathrm{mg}$.

Slaughter and carcass: At 35 days of age, slaughter of birds was performed using three chickens selected according to average live body weight of each treatment. carcass characteristics as dressed carcass, liver, heart, gizzard, 
giblets and edible parts were estimated as a percentage in relation to live weight of birds.

Blood plasma: Blood samples of chosen chickens were taken during slaughtering into collecting tubes with heparin. Plasma were separated by centrifugation at speed of $3000 \mathrm{rpm}$ for about 10 minutes, then transferred into clean vials and stored in a deep freezer for later analyses. Plasma constituents including total protein, albumin, creatinine, urea, uric acid, calcium, phosphorus and activity of alkaline phosphatase were determined calorimetrically by commercial diagnostic kits using a spectrophotometer.

Tibia bones: Tibia bone traits were recorded as described; volume (Zhang and Coon, 1992), Seedor index (Seedor et al., 1991), Robusticity index (Reisenfeld, 1975) and Breaking force (Rowland et al. 1967).

Economical traits: Economic assessment and production cost analysis were carried out for all groups to investigate effects of different feed additives inclusion on relative economic efficiency.

Statistical Analysis: Data were analyzed using the general linear model (GLM) procedure of SAS (2004). Means were compared using Duncan's Multiple Rang test (Duncan, 1955).

The statistical model was: $\mathrm{Yij}=\mu+\mathrm{Ti}+$ eij

Where: Yij = observation of measured parameter, $\mu=$ overall mean $\mathrm{Ti}=\operatorname{diet}$ treatment ( $\mathrm{i}: 1$ to 5$)$, eij = experimental error

\section{RESULTS AND DISCUSSION}

Productive performance: As shown in Table (2), values of live body weight (LBW), daily body weight gain (DBWG), daily feed intake (DFI) and feed conversion ratio (FCR), were not significant different between basal diet and 
all treatments. However, numerically, (T4) had the lowest one in LBW and DBWG. Also, (T2) and (T3) were the best treatments for FCR. That's mean, these additives had no effects on the growth performance, but improved FCR especially Sodium formate, and formic acid little bit than other treatments, but these differences failed to reach significances. These results in agreement with those of Higgins et al., (2008); El-Faham et al., (2014) and Abdelaziz (2015).

Table (2): Effect of treatments on productive performance

\begin{tabular}{|c|c|c|c|c|c|c|}
\hline \multirow{2}{*}{ Items } & \multicolumn{5}{|c|}{ Experimental Treatments } & \multirow{2}{*}{ Sig. } \\
\cline { 2 - 6 } & T1 & T2 & T3 & T4 & T5 & \\
\hline \hline LBW (g) & 38.83 & 38.44 & 38.73 & 39.60 & 40.09 & \multirow{2}{*}{ NS } \\
(1 day) & \pm 0.01 & \pm 0.01 & \pm 0.01 & \pm 0.01 & \pm 0.01 & \\
\hline LBW (g) & 1859.58 & 1888.70 & 1883.38 & 1770.01 & 1806.30 & \multirow{2}{*}{ NS } \\
(35 days) & \pm 60.45 & \pm 29.62 & \pm 62.21 & \pm 25.01 & \pm 44.16 & \\
\hline DBWG (g/ day) & 52.02 & 52.86 & 52.70 & 49.44 & 50.46 & \multirow{2}{*}{ NS } \\
(0-35 days) & \pm 1.72 & \pm 0.84 & \pm 1.77 & \pm 0.71 & \pm 1.25 & \\
\hline DFI (g/day) & 84.25 & 82.48 & 83.10 & 82.72 & 84.02 & \multirow{2}{*}{ NS } \\
(0-35 days) & \pm 0.30 & \pm 1.04 & \pm 2.79 & \pm 2.53 & \pm 1.36 & \\
\hline FCR & 1.62 & 1.56 & 1.57 & 1.67 & 1.66 & \multirow{2}{*}{ NS } \\
(0-35 days) & \pm 0.04 & \pm 0.02 & \pm 0.01 & \pm 0.04 & \pm 0.04 & \\
\hline
\end{tabular}

Sig. = Significance, NS: Non-Significant.

Similar observation was reported by Loddi et al., (2000) who found that there were no beneficial effects of probiotic supplementation and negative influenced body weight and weight gain of broilers. On the other hand, these results were in contrast with the results obtained by Tollba et al. (2004), Nagla et al. (2012), Awad et al. (2013) and Nematallah et al. (2015) who reported that increased significantly adding the tested biological additives or different types of organic acids increased significantly live body weight and 
weight gain than control, these additives or different types of organic acids and their salts improved protein and energy digestibility by reducing microbial competition with birds for nutrients. Also, this limits endogenous nitrogen loss with decreasing occurrence of sub-clinical contamination. Also, reducing the production of ammonia as indirect effect and other growth suppressing microbial metabolites. So, broilers that fed organic acids or their salts can be improved nutrient utilization, enlarged gut surface and counteract potential pathogenic bacteria without any significant differences as reported by Vale et al. (2004); Leeson et al. (2005) and Gunal et al. (2006).

Carcass characteristics: Table (3) showed the carcass traits as affected by treatments. All traits were not significantly affected by treatments. However, numerically dressed carcass percentage had the lowest in T3 and T4. Also, numerically, gizzard percentage was the highest in value T5 than other treatments and control. These results in agreement with those postulated by Abdel-Azeem and Hamid (2000); El-Yamny and Fdel (2004) and Nematallah et al., (2015) who reported that growth promoters had no significant differences among all groups in carcass weight and dressing percentage. These results are in contrast with the results obtained by Leeson et al., (2005) in broiler chickens and Abdel-Mageed (2012) in Japanese quail. They found that feeding butyric acid supplemented diets lead to significantly increased on carcass parameters. 
J. Environ. Sci.

Institute of Environmental Studies and Research - Ain Shams University

Table (3): Effect of treatments on some carcass characteristics

\begin{tabular}{|c|c|c|c|c|c|c|}
\hline \multirow{2}{*}{ Items } & \multicolumn{7}{|c|}{ Experimental Treatments } & \multirow{2}{*}{ Sig. } \\
\cline { 2 - 6 } & T1 & T2 & T3 & T4 & T5 & \\
\hline \hline \multirow{2}{*}{ Dressed carcass \% } & 71.06 & 70.14 & 68.15 & 68.67 & 69.71 & \multirow{2}{*}{ NS } \\
& \pm 1.23 & \pm 0.14 & \pm 0.21 & \pm 1.04 & \pm 0.95 & \\
\hline \multirow{2}{*}{ Liver \% } & 2.41 & 2.19 & 2.24 & 2.24 & 2.17 & \multirow{2}{*}{ NS } \\
& \pm 0.12 & \pm 0.20 & \pm 0.17 & \pm 0.15 & \pm 0.10 & \\
\hline \multirow{2}{*}{ Gizzard \% } & 0.90 & 0.93 & 0.79 & 0.89 & 1.10 & \multirow{2}{*}{ NS } \\
& \pm 0.08 & \pm 0.08 & \pm 0.06 & \pm 0.05 & \pm 0.02 & \\
\hline \multirow{2}{*}{ Heart \% } & 0.52 & 0.56 & 0.59 & 0.54 & 0.52 & \multirow{2}{*}{ NS } \\
& \pm 0.04 & \pm 0.03 & \pm 0.02 & \pm 0.02 & \pm 0.04 & \\
\hline \multirow{2}{*}{ Giblets¥\% } & 4.20 & 4.20 & 4.19 & 4.12 & 4.28 & \multirow{2}{*}{ NS } \\
& \pm 0.16 & \pm 0.24 & \pm 0.24 & \pm 0.18 & \pm 0.21 & \\
\hline \multirow{2}{*}{ Total Edible Parts \# \% } & 75.27 & 74.34 & 72.34 & 72.79 & 74.01 & \multirow{2}{*}{ NS } \\
\hline \hline
\end{tabular}

Sig. = Significance, ¥ Giblets = Liver + Gizzard + Heart, \# Total Edible Parts = (dressed carcass + giblets), NS: Non-Significant.

Blood plasma parameters: Effect of treatments on some blood parameters illustrated in Table (4). Total protein had significant difference, and that related to growth performance and that means these additives had improved growth and the best one that birds fed (T2) and the lowest one was (T4). Although albumin and globulin had no significant difference, but (T2) and (T3) had the best values compared with control and other treatments. Also, globulin value for birds that fed (T2) had better than other treatments and control numerically. That's mean bird's immunity had improved by this treatment. Concerning to $\mathrm{A} / \mathrm{G}$ ratio, the best treatment was (T5) then control compared with other treatments. Regarding to kidney function; creatinine and urea values were not significant different between treatments and control. So, these additives had no adverse effects on kidney function. About uric acid concentration, the highest value was recorded for (T5) compared with control 
and other treatments. So, enzyme supplemented had a worse effect on kidney function or this enzyme had effect and increased the protein metabolism than other treatments and control that led to increase uric acid concentration in blood. Concerning to calcium values, (T2) and (T4) had increased Ca levels than other treatments and control, and (T5) the lowest value. Phosphorus concentration, control and (T3) had the highest values than other treatments. That's mean these treatments had increased the $\mathrm{Ca}$, and $\mathrm{P}$ metabolism. Regarding to activity of alkaline phosphatase (ALP), (T4) had the lowest one then (T3) compared to control and other treatments. It's worthy to note that (T3) and (T4) had decreased the ALP concentration and the differences had highly significant $(\mathrm{P} \leq 0.01)$. It's logically ALP activity and $\mathrm{Ca}$ and $\mathrm{P}$ concentrations have related to each other. When $\mathrm{Ca}$ and $\mathrm{P}$ concentrations decreased, the activity of ALP increased in the serum of broilers (Rama Rao et al., 2006).

These results are disagreement with those reported by many investigators (Kalavathy et al., 2003; Abdel-Azeem and Hamid, 2006; Abdallah et al., 2008; Nematallah et al., 2015). They reported that there were no significant differences in blood parameters (Tp., Alb., and Glo), due to probiotic supplementation. On the other hand, Tollba et al., (2004) postulated that adding probiotic additives to broiler feeds increase plasma Tp, Alp, Glo, compared to control. 
J. Environ. Sci.

Institute of Environmental Studies and Research - Ain Shams University

Table (4): Effect of treatments on some blood plasma parameters

\begin{tabular}{|c|c|c|c|c|c|c|}
\hline \multirow{2}{*}{ Items } & \multicolumn{5}{|c|}{ Experimental Treatments } & \multirow{2}{*}{ Sig. } \\
\hline & T1 & $\mathbf{T 2}$ & T3 & T4 & T5 & \\
\hline Total Protein g / dL & $\begin{array}{l}3.75^{\text {ab }} \\
\pm 0.37\end{array}$ & $\begin{array}{l}3.97^{\mathrm{a}} \\
\pm 0.23\end{array}$ & $\begin{array}{c}3.73 \mathrm{ab} \\
\pm 0.21\end{array}$ & $\begin{array}{l}3.09^{\mathrm{b}} \\
\pm 0.10\end{array}$ & $\begin{array}{l}3.66^{\mathrm{ab}} \\
\pm 0.17\end{array}$ & $*$ \\
\hline Albumin g / dL & $\begin{array}{c}1.89 \\
\pm 0.09\end{array}$ & $\begin{array}{c}2.06 \\
\pm 0.06\end{array}$ & $\begin{array}{c}1.98 \\
\pm 0.05\end{array}$ & $\begin{array}{c}1.89 \\
\pm 0.05\end{array}$ & $\begin{array}{c}1.81 \\
\pm 0.13\end{array}$ & NS \\
\hline Globulin g / dL & $\begin{array}{c}1.85 \\
\pm 0.28\end{array}$ & $\begin{array}{c}1.91 \\
\pm 0.19\end{array}$ & $\begin{array}{c}1.74 \\
\pm 0.17\end{array}$ & $\begin{array}{c}1.20 \\
\pm 0.11\end{array}$ & $\begin{array}{c}1.85 \\
\pm 0.23\end{array}$ & NS \\
\hline Albumin/ Globulin ratio & $\begin{array}{c}1.06^{\mathrm{b}} \\
\pm 0.12\end{array}$ & $\begin{array}{l}1.10^{\mathrm{ab}} \\
\pm 0.11\end{array}$ & $\begin{array}{l}1.15^{\mathrm{ab}} \\
\pm 0.10\end{array}$ & $\begin{array}{l}1.61^{\mathrm{a}} \\
\pm 0.18\end{array}$ & $\begin{array}{l}1.03 \mathrm{~b} \\
\pm 0.21\end{array}$ & NS \\
\hline Creatinine $\mathrm{mg} / \mathrm{dL}$ & $\begin{array}{c}0.47 \\
\pm 0.03\end{array}$ & $\begin{array}{c}0.47 \\
\pm 0.03\end{array}$ & $\begin{array}{c}0.52 \\
\pm 0.09\end{array}$ & $\begin{array}{c}0.46 \\
\pm 0.02\end{array}$ & $\begin{array}{c}0.39 \\
\pm 0.01\end{array}$ & NS \\
\hline Urea mg / dL & $\begin{array}{c}7.10 \\
\pm 0.78\end{array}$ & $\begin{array}{c}6.93 \\
\pm 0.73\end{array}$ & $\begin{array}{c}7.50 \\
\pm 0.60\end{array}$ & $\begin{array}{c}8.76 \\
\pm 0.52\end{array}$ & $\begin{array}{c}8.50 \\
\pm 1.81\end{array}$ & NS \\
\hline Uric Acid mg / dL & $\begin{array}{l}4.38^{\mathrm{c}} \\
\pm 0.16\end{array}$ & $\begin{array}{l}4.84^{\mathrm{c}} \\
\pm 0.43\end{array}$ & $\begin{array}{l}6.41^{b} \\
\pm 0.38\end{array}$ & $\begin{array}{l}6.31^{\mathrm{b}} \\
\pm 0.80\end{array}$ & $\begin{array}{l}8.72^{\mathrm{a}} \\
\pm 0.23\end{array}$ & $* *$ \\
\hline Calcium mg / dL & $\begin{array}{c}10.46^{\mathrm{bc}} \\
\pm 0.40\end{array}$ & $\begin{array}{l}13.10^{\mathrm{a}} \\
\pm 0.66\end{array}$ & $\begin{array}{c}10.60^{\mathrm{bc}} \\
\pm 0.72\end{array}$ & $\begin{array}{c}11.93^{\mathrm{ab}} \\
\pm 0.46\end{array}$ & $\begin{array}{l}9.50^{c} \\
\pm 0.73\end{array}$ & $* *$ \\
\hline Phosphorus mg / dL & $\begin{array}{l}3.98^{\mathrm{ab}} \\
\pm 0.16\end{array}$ & $\begin{array}{l}4.83^{\mathrm{a}} \\
\pm 0.40\end{array}$ & $\begin{array}{l}3.96^{\mathrm{ab}} \\
\pm 0.04\end{array}$ & $\begin{array}{l}4.92^{\mathrm{a}} \\
\pm 0.52\end{array}$ & $\begin{array}{c}3.43^{\mathrm{b}} \\
\pm 0.12\end{array}$ & $*$ \\
\hline ALP U/L & $\begin{array}{l}2885^{\mathrm{b}} \\
\pm 185\end{array}$ & $\begin{array}{l}2732^{b} \\
\pm 287\end{array}$ & $\begin{array}{l}2065^{\mathrm{c}} \\
\pm 153\end{array}$ & $\begin{array}{c}1853^{\mathrm{c}} \\
\pm 65\end{array}$ & $\begin{array}{l}3470^{\mathrm{a}} \\
\pm 159\end{array}$ & $* *$ \\
\hline
\end{tabular}

$\mathrm{a}, \mathrm{b}$ Means within the same row with different superscripts are significantly different. Sig. $=$ Significance, ${ }^{* *}(\mathrm{P} \leq 0.01),{ }^{*}(\mathrm{P} \leq 0.05)$. NS: Non-Significant.

Tibia traits: Table (5) showed the effect of treatments on some tibia indices. Although there were not significant differences between control and other treatments, but numerically tibia breaking force had the best values for (T4) and (T5) and that's mean these additives improved the breaking force than control and other treatments. Also, density of tibia for (T3) and (T4) had the highest values than control and other treatments and these results had harmonious with ALP concentrations levels, and that led to these treatments improved the density of tibia. Finally, (T3) and (T5) had the highest values 
for tibia Seedor index than control and other treatments. It's worth to note that most of the additives had improved the growth performance, carcass traits, some blood parameters and tibia indices without any adverse effect on bird's health and that elucidated by blood parameters.

Table (5): Effect of treatments on some tibia indices

\begin{tabular}{|c|c|c|c|c|c|c|}
\hline \multirow{2}{*}{ Items } & \multicolumn{5}{|c|}{ Experimental Treatments } & Sig. \\
\cline { 2 - 7 } & T1 & T2 & T3 & T4 & T5 & \\
\hline \hline \multirow{2}{*}{ Tibia Breaking Force (Kg) } & 25.16 & 25.37 & 26.35 & 31.52 & 31.36 & \multirow{2}{*}{ NS } \\
& \pm 2.41 & \pm 4.31 & \pm 2.79 & \pm 2.04 & \pm 2.59 & \\
\hline \multirow{2}{*}{ Tibia Density (g/ cm $)$} & 1.19 & 1.19 & 1.22 & 1.22 & 1.18 & \multirow{2}{*}{ NS } \\
& \pm 0.01 & \pm 0.02 & \pm 0.01 & \pm 0.01 & \pm 0.01 & \\
\hline \multirow{2}{*}{ Tibia Robusticity Index } & 3.96 & 3.91 & 3.95 & 3.94 & 3.91 & \multirow{2}{*}{ NS } \\
& \pm 0.05 & \pm 0.07 & \pm 0.03 & \pm 0.04 & \pm 0.06 & \\
\hline \multirow{2}{*}{ Tibia Seedor Index } & 1.19 & 1.24 & 1.33 & 1.29 & 1.33 & \multirow{2}{*}{ NS } \\
& \pm 0.08 & \pm 0.05 & \pm 0.01 & \pm 0.06 & \pm 0.06 & \\
\hline
\end{tabular}

$\mathrm{a}, \mathrm{b}, \mathrm{c}, \mathrm{d}$ Means within the same row with different superscripts are significantly different. Sig. $=$ Significance, $* *(\mathrm{P} \leq 0.01), *(\mathrm{P} \leq 0.05)$.

Economic parameters: Calculations economic efficiency of feeds were carried out according to the prices of feed ingredients, additives and live body weight as shown in Table (6). Feeding relative economic efficiency values of broiler chickens were improved by 107.75 and $103.85 \%$ for the groups fed diets supplemented with sodium formate (T2) and formic acid (T3), respectively when compared to control (T1) group (100\%) during overall period (0-35 days). On the other hand, chickens fed diets supplemented with Lactobacillus acidophilus or beta mannanase (T4 and T5) had lower values, being 84.62 and $90.52 \%$, respectively. 
J. Environ. Sci.

Institute of Environmental Studies and Research - Ain Shams University

Table (6): Effect of treatments on some economic traits

\begin{tabular}{|c|c|c|c|c|c|}
\hline & \multicolumn{5}{|c|}{ Experimental Treatments } \\
\hline Items & T1 & T2 & T3 & T4 & T5 \\
\hline \hline \multirow{2}{*}{ Feed Cost / Bird (LE) } & 18.87 & 18.61 & 18.88 & 18.90 & 18.90 \\
& \pm 0.07 & \pm 0.22 & \pm 0.63 & \pm 0.58 & \pm 0.31 \\
\hline \multirow{2}{*}{ Total Cost ${ }^{¥}$ / Bird (LE) } & 31.87 & 31.61 & 31.88 & 31.90 & 31.92 \\
& \pm 0.07 & \pm 0.22 & \pm 0.63 & \pm 0.58 & \pm 0.31 \\
\hline \multirow{2}{*}{ Total Return" Bird (LE) } & 46.49 & 47.22 & 47.08 & 44.25 & 45.15 \\
& \pm 1.51 & \pm 0.74 & \pm 1.55 & \pm 0.62 & \pm 1.10 \\
\hline \multirow{2}{*}{ Net Return / Bird (LE) } & 14.61 & 15.60 & 15.19 & 12.35 & 13.23 \\
& \pm 1.44 & \pm 0.66 & \pm 0.92 & \pm 0.56 & \pm 1.02 \\
\hline \multirow{2}{*}{ Economic Efficiency } & 45.82 & 49.37 & 47.58 & 38.77 & 41.48 \\
& \pm 4.47 & \pm 2.06 & \pm 1.92 & \pm 2.15 & \pm 3.16 \\
\hline \multirow{2}{*}{ Relative Economic Efficiencyø } & \multirow{2}{*}{100.00} & 107.75 & 103.85 & 84.62 & 90.52 \\
& & \pm 4.50 & \pm 4.20 & \pm 4.70 & \pm 6.90 \\
\hline \hline
\end{tabular}

$¥$ Total cost $=$ (feed cost + price of one-day live chicks + incidental costs); L.E.:

Egyptian Pound

\# According to the local price of $\mathrm{Kg}$ sold live birds which was 25.00 L.E.

assuming that the relative economic efficiency of control group equals 100 .

These results agreed with those of El-Faham et al. (2014) who found that chicks fed diets contained with Lactobacillus acidophilus had lower relative economic efficiency when compared to control group. Additionally, Abdelaziz (2015) indicated that, sodium formate as feed additive could be included at different levels in broiler feeds presenting better economic efficiency of feeds. These results are in contrast with those of Qota et al. (2002) who reported insignificant effect of probiotic supplementation on economic efficiency of broiler feeds up to 42 days of age. Alternatively, Soliman et al. (2003) found that inclusion of probiotic or herbal feed 
additives in broiler feeds, resulted in least feed cost per kg gain and the higher percent of economic efficiency as compared with control group.

\section{CONCLUSION}

Thus, it could be concluded that, supplementation of basal diets with formic acid or its sodium salt, enhanced performance and economic efficiency of broiler chickens. These additives present a promising tool for reducing the risk environmental pollution with phosphorus and/ or nitrogen through better utilization of these elements in poultry feeds.

\section{REFERENCES}

Abdalla, E.; A. Soher; Y. Saleh; S. Mary and A. Hathout (2008): Probiotic bacteria as a tool to produce high quality and safe Ras cheese. Egypt. J. Dairy Sci., 36: 97-109.

Abdel-Azeem, F. and A. A. Hamid (2006): Using barley radical with yeast cultures supplementation in broilers diets. Egypt. Poult. Sci., 26(1): 179-206.

Abdelaziz, M. A. M. (2015): Effect of phosphorus restriction in presence of organic acid salt on bone quality and mineral digestibility of broilers. Egypt. Poult. Sci. 35: 961-977.

Abdelhady, A.Y.M.; H.A. El-Alaily; S.A. Ibrahim and M.A.M. Abdelaziz (2015): Effect of using sodium formate with restricted calcium and phosphorus on broiler performance and gut health. Egypt. J. Nutr. and feeds, 18(2) special Issue: 431-441.

Abdel-Mageed, M.A.A. (2012): Effect of using organic acids on performance of Japanese quail fed optimal and sub-optimal energy and protein levels. 2-Butyric acid. Egypt. Poult. Sci., 32(1): 625-644. 
Arogo, J.; P.W. Westerman; A.J. Heber; W.P. Robarge and J.J. Classen (2001): Ammonia in animal production - a review. Paper number 014089, ASAE Annual Meeting July 30- August 1, Sacramento, USA. American Society of Agricultural and Biological Engineers.

Andreopoulou M.; V. Tsiouris and I. Georgopoulou (2014): Effects of organic acids on the gut ecosystem and on the performance of broiler chickens. J. Hellenic. Vet. Med. Soc., 65: 289-302.

Awad, A.L.; A.I.A. Ghonim; M.H.A. Fatouh and M.F. Soliman (2013): Effect of supplementing Some growth promoters to duckling diets on growth performance and carcass traits under summer condition. Egypt Poult. Sci. 33: 371-391.

Campasino, A.; M. Williams; R. Latham; C.A. Bailey; B. Brown and J.T. Lee (2015): Effects of increasing dried distillers' grains with solubles and non-starch polysaccharide degrading enzyme inclusion on growth performance and energy digestibility in broilers. J. Appl. Poult. Res., 24: 135-144.

Cowieson, A. J. (2010): Strategic selection of exogenous enzymes for corn/soy-based poultry diets. Poult. Sci., 47:1-7.

Cross, M. L. (2002): Microbes versus microbes: immune signals generated by probiotic lactobacilli and their role in protection against microbial pathogens. FEMS. 1mmunol. Medical Microbial, 34: 245-253.

Dalloul, R. A, H.S. Lillehoj, T.A. Shellem and J.A. Doerr (2003): Enhanced mucosal immunity against Eimeria acervulina in broilers fed a Lactobacillus-based probiotic. Poult. Sci., 82: 62-66.

Dersjant-Li, Y.; K. van der Belt; J.D. van der Klis; H. Kettunen; T. Rinttila and A. Awati (2015): Effect of multi-enzymes in combination with a direct-fed microbial on performance and welfare parameters in broilers under commercial production settings. J. Appl. Poult. Res., 24: 80-90.

Desai, D.; D. Pantwardhan and A. Ranade (2007): Acidifiers in poultry production. Nottingham Univ., Press Nottingham, pp. 63-69.

Duncan, D.B. (1955): Multiple ranges and multiple F test. Biometrics, 11: 142. 
El-Faham A.; N.G. Ali and H.M. El-Maaty (2014): Effect of using some natural feed additives to substitute antibiotic growth promoters on performance and blood parameters of broilers. Egypt. Poult. Sci., 34: 735-750.

El-Yamny, A.T. and M. Fadel (2004): The influence of supplemented fungi or active yeast as growth promoter for diets of growing Japanese quail on the performance, metabolic responses and economic efficiency. Egypt. Poult. Sci., 24: 963-976.

Emmert, J. (2000): Efficiency of phase feeding in broilers. Proceeding, California Animal Nutrition Conference. Fresno California, USA.

FAO. (2006) Livestock's long shadow: environmental issues and options, by H. Steinfeld, P. Gerber, T. Wassenaar, V. Castel, M. Rosales \& C. de Haan. Rome.

Gunal, M.; G. Yaylo; O. Kaya; N. Karahan and O. Sulak (2006): The effect of antibiotic growth promoter. Probiotic or organic acid supplementation on performance, intestinal microflora and tissue of broilers. Int. J. Poult. Sci., 5(2): 149-155.

Hahn-Didde, D. and S.E. Purdum (2014): The effects of an enzyme complex in moderate and low nutrient-dense diets with dried distillers' grains with solubles in laying hens. J. Appl. Poult. Res., 23: 2333.

Hebeler, D.; S. Kulla and G. Amtsberg (2000): Influence of a formic acidpotassium formate complex on chyme composition as well as on the intestinal microflora of weaned piglets Proceedings of the Society of Nutrition Physiology 9: 63.

Helen, B. and L. Christian (2010): Performance enhancement through the use of diformate in broiler. ADDCON company, Germany.

Higgins, S.E.; J.P. Higgins; A.D. Wolfenden; S.N. Henderson; A. TorresRodriguez; G. Tellez and B. Hargis (2008): Evaluation of Lactobacillus-based probiotic culture for the reduction of Salmonella Enteritidis in neonatal broiler chicks. Poult. Sci., 87: 27-31. 
Kalavathy, R.; N. Abdullah; S. Jalaludin and Y.W. Ho (2003): Effects of Lactobacillus cultures on growth performance, abdominal fat deposition, serum lipids and weight of organs of broiler chickens. Br. Poult. Sci., 44: 139-144.

Leeson, S.; H. Namkung; M. Antongiovanni and E.H. Lee (2005): Effect of butyric acid on the performance and carcass yield of broiler chickens. Poult. Sci., 84: 1418-1422.

Loddi, M.M.; E. Gonzales; T.S. Takita; A.A. Mendes and R. de-O.Roca (2000): Effect of the use of probiotic and antibiotic on the performance and carcass quality of broilers. Revista-Brasileira de Zootecnia, 29: 1124-1131.

Makled, M.N. (1991): The potentials of probiotic in poultry feed. A Review Proceeding 3rd Sci. Symp. for Animal, Poultry and Fish Nutrition, 11: 54-68. Kafr-Elsheikh, Egypt.

Nagla K. Soliman; Y.M. Abyoussef and Nevine B. Ghanem (2012): Improving broiler performance and feed efficiency by adding organic acid to broiler diets. Egypt. J. Nutri Feeds 15(2): 393-404.

Nahm, K.H. and C.W. Carlson (1998): The possible minimum chicken nutrient requirements for protecting the environment and improving cost efficiency (A review). Asia-Austr. J. Anim. Sci., 11: 755-768.

Nematallah, G.M. Ali; A.F. Abdel-Salam; G.M. El-Gendi; A.A. Radwan and Heba Allah E. Megahid (2015): Modulation of physiological and microbiological broiler state by some growth promoters. Egypt. Poult. Sci. 35: 591-608.

NRC (1994): National Research Council. Nutrient Requirements of Poultry 9th Ed. Composition of Poultry Feedstuffs National Academy Press, Washington, DC, USA. P.P. 61-75.

Panda, A.K..; S.V. Raju Rama; G. Shyam Sunder and M.R. Reddy (2009): Effect of graded levels of formic acid on gut microflora count, serum biochemical parameters, performance and carcass yield of broiler chickens. Indian, J. Anim. Sci. 79: 1165-1168. 
Perazzo Costa, FG; M.R. Lima; M.L. Ceccantini; R.M. Neto; C.C. Goulart; C.F.S. Oliveira; D.V.G. Vieira and C.S. Santos (2015): Exogenous enzyme complexes and linoleic acid to laying hens. J. Appl. Poult. Res., 24: 30-36.

Qota, E.M.A.; A.A. El-Ghamry and G.M. El-Mallah (2002): Nutritive value of soaked linseed cake as affected by phytase, biogen supplementation or formulating diets based on available amino acids on broilers performance. Egypt. Poult. Sci., 22(2): 461-475.

Rama Rao, S.V., M.V.L.N. Raju, M.R. Reddy and P. Pavani (2006): Interaction between dietary calcium and non-phytate phosphorus levels on growth, bone mineralization and mineral excretion in commercial broilers. Anim. Feed Sci. Technol., 132:135-150.

Reisenfeld, A.: Endocrine control of skeletal robusticity (1975): Acta Anatomica, 91: 481-499.

Rowland, L.O. Jr.; R.H. Harms; H.R. Wilson; J.J. Ross and J.L. Fry (1967): Breaking strength of chick bones as an indication of dietary calcium and phosphorus adequacy. Exp. Biol. Med., 126: 399-401

SAS (2004): SAS procedure guide Version 6. 12th Ed. SAS institute Inc. Cary, NC and U.C.A.

Seedor, J. G., Quarruccio, H.A., Thompson, D.D.: The biophosphonate alendronate (MK-217) inhibits bone loss due to ovariectomy in rats. J Bone Miner Res. 1991; 6: 339-346.

Seleem, T.S.T.; M.A.F. El-Manylawi; Y.M. Ragab and I.I. Omara (2011): Mature California rabbit performance as affected by prebiotic or/ and probiotics in drinking water. Egypt. J. Nutr. and Feeds, 14(2): 239-250.

Selle, P.H.; K.H. Huang and W.I. Muir (2004): Effects of potassium diformate inclusion in broiler diets on growth performance and nutrient utilization. Proceedings Aust. Poult. Sci. Symposium: 5558. 
Soliman, A.Z.M.; M.A. Ali and Z.M.A. Abdo (2003): Effect of marjoram, bacitracin and active yeast as feed additives on the performance and the microbial content of the broiler's intestinal tract. Egypt Poult. Sci. 23: 445-467.

Tollba, A.A.H.; M.M. Sabry and G.G. Medani (2004): Effect of microbial probiotics on performance of broiler chicks under normal or heat stress conditions. Egypt Poult. Sci. 24(II): 333-249.

Vale, M.M.; J.F.M. Menten; S.C.D. Morais and M.M.A. Brainer (2004): Mixture of formic and propionic acid as additives in broiler feeds. Sci. Agric. Braz., 61(4): 371-375.

Yang, Z.B., W.R. Yang; S.Z. Jiang; G.G. Zhang; Q.Q. Zhang and K.C. Siow (2010): Effects of a thermotolerant multi-enzyme product on nutrient and energy utilization of broilers fed mash or crumbled corn-soybean meal diets. J. Appl. Poult. Res., 19: 38-45.

Zhang, B. and C.N. Coon (1992).: Nutrition Institute on Minerals. Chapter 7. Practical Applications. National Feed Ingredient Association, Chicago, IL. 


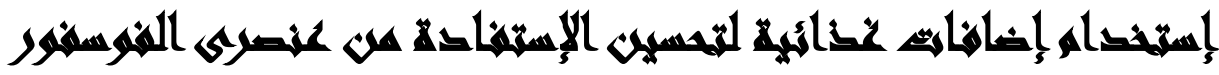

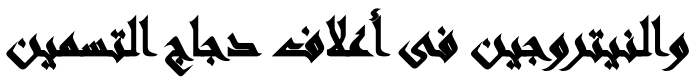

\section{[}

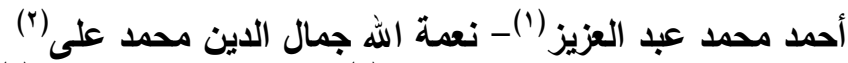

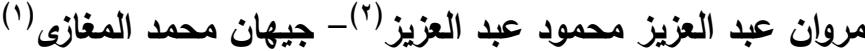

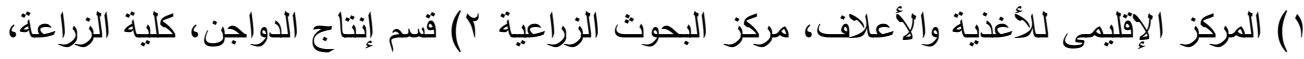

\section{المستحلى}

أجريت تجربة للتعرف على تأثثر إضافة فورمات صوديوم، حامض فورميك، لاكتوباسيلس

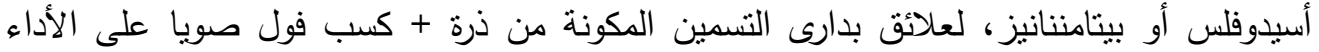

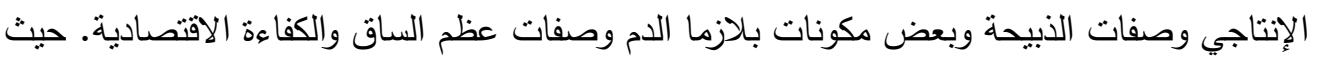
استخدم فى التجربة عدد ،10 كتكوت اربوايكرز عمر يوم ووزعت الإت على ولى (خمس معاملات غذائية)

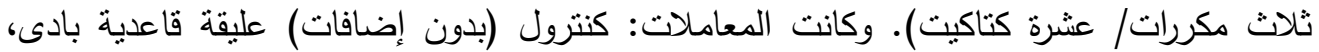

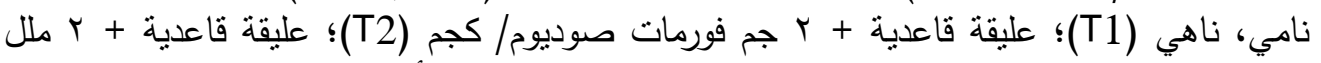

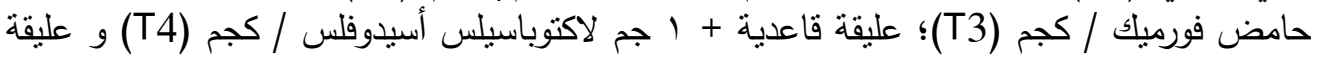

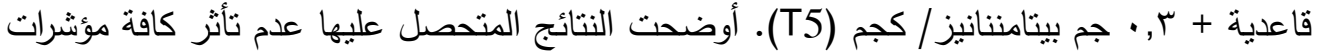

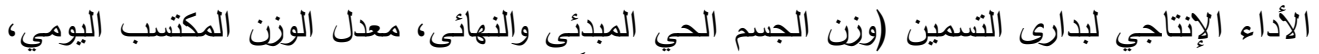

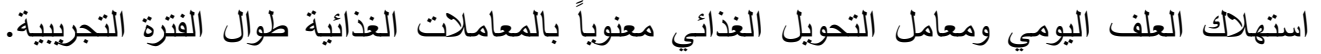

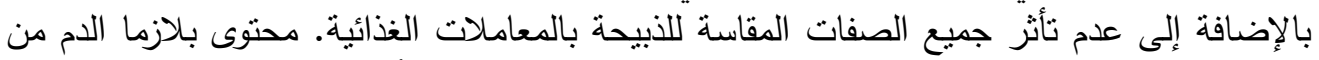

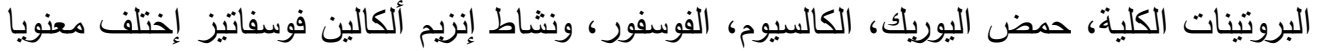

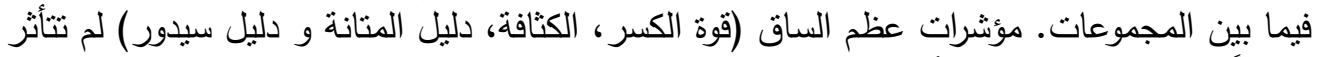

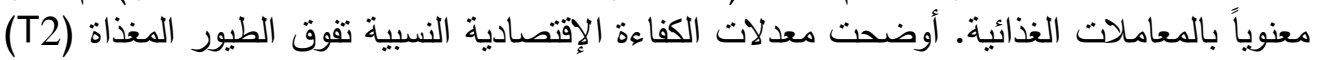

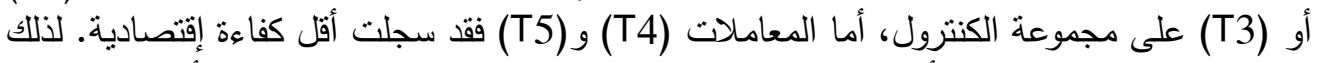
فإن إضافة فورمات صوديوم أو حمض الفورميك إلى العلائق القاعدية لبدارى التسمين أدى إلى تحسن

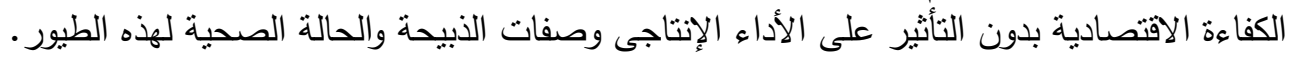

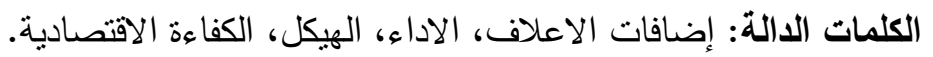

